\title{
Associated auto-immune disease in type 1 diabetes patients: a systematic review and meta-analysis
}

\section{Nederstigt ${ }^{1,2}$, B S Uitbeijerse ${ }^{3, *}$, L G M Janssen ${ }^{1, *}$, E P M Corssmit ${ }^{1}$, E J P de Koning ${ }^{1,3}$ and O M Dekkers ${ }^{1,2,4}$}

\begin{abstract}
${ }^{1}$ Department of Internal Medicine, Section Endocrinology \& Metabolism, ${ }^{2}$ Department of Clinical Epidemiology, ${ }^{3}$ Department of Nephrology, Leiden University Medical Center, Leiden, The Netherlands, and ${ }^{4}$ Department of Clinical Epidemiology, Aarhus University Hospital, Aarhus, Denmark
\end{abstract}

Correspondence should be addressed to C Nederstigt Email c.nederstigt@lumc.nl

\begin{abstract}
Introduction: The association between type 1 diabetes (T1D) and other auto-immune diseases is well known. However, a quantitative overview of all associated auto-immune diseases and their prevalence in T1D is lacking. Methods: We searched PubMed, Web of Science, EMBASE and Cochrane library in September 2018 to identify relevant articles about the prevalence of the following associated auto-immune diseases in T1D cohorts: auto-immune thyroid disease, celiac disease, gastric autoimmunity including pernicious anemia, vitiligo and adrenal gland insufficiency. A meta-analysis was performed to estimate pooled prevalence using a random-effects model. Furthermore, randomeffects meta-regression analysis was performed to assess the association between prevalence and mean age or diabetes duration.

Results: One hundred eighty articles were eligible including a total of 293889 type 1 diabetes patients. Hypothyroidism (65 studies) was prevalent in $9.8 \%$ (95\% Cl: 7.5-12.3) of patients. Meta-regression showed that for every 10-year age increase, hypothyroidism prevalence increased $4.6 \%$ (95\% Cl: 2.6-6.6, $P<0.000,54$ studies). Weighted prevalence of celiac disease was $4.5 \%$ (95\% Cl: 4.0-5.5, 87 studies). Gastric autoimmunity was found in $4.3 \%$ of patients $(95 \% \mathrm{Cl}$ : $1.6-8.2,8$ studies) and vitiligo in $2.4 \%$ (95\% Cl: 1.2-3.9, 14 studies) of patients. The prevalence of adrenal insufficiency was $0.2 \%$ (95\% Cl: $0.0-0.4,14$ studies) and hyperthyroidism was found in 1.3 percent (95\% Cl: 0.9-1.8, 45 studies) of type 1 diabetes patients. For all analyses, statistical heterogeneity between studies was moderate to high. Conclusions: The prevalence of antibody-mediated auto-immune disease is high among type 1 diabetes patients. Especially hypothyroidism and celiac disease are frequently found.
\end{abstract}

\section{Introduction}

Type 1 diabetes is an endocrine disorder characterized by the destruction of insulin-producing pancreatic beta cells, in which $\mathrm{T}$ cells play a central role $(1,2,3)$. Type 1 diabetes patients have a higher risk of other auto-immune diseases, in particular thyroid diseases and celiac disease $(4,5,6)$. Associated antibodies are also frequently found among these patients, sometimes coinciding with overt, (c) 2019 European Society of Endocrinology Printed in Great Britain
European Journal of Endocrinology

(2019) 180, 135-144 but often subclinical disease $(7,8)$. Moreover, it was shown that type 1 diabetes patients have more gastric autoimmunity, vitiligo and adrenal gland insufficiency $(9,10,11,12,13,14,15,16,17)$. It was shown that the pathogenesis of these diseases share common genetic factors and immunologic processes, key to the etiology of the disease $(18,19,20,21,22)$. 
Concomitant auto-immune disease in type 1 diabetes patients not only can complicate diabetes management $(23,24)$ but also can lead to varying clinical symptoms, ranging from minor complaints up till potential lifethreatening situations in case of adrenal insufficiency (25, 26). Thus, substantiated estimates of risk of auto-immune disease followed by the development of optimal screening and treatment strategies is important for type 1 diabetes patients, also contributing to better glucose regulation and quality of life $(27,28)$.

An increased prevalence of concomitant auto-immune diseases in type 1 diabetes has often been reported but a complete overview is lacking. The aim of the present systematic review and meta-analysis is to provide a quantitative overview of the prevalence of associated auto-immune diseases in type 1 diabetes patients, thereby contributing to the knowledge base of screening polices in these patients.

\section{Methods}

\section{Data sources and searches}

We searched PubMed, Web of Science, EMBASE and Cochrane library in September 2018 to identify potentially relevant articles reporting prevalence of associated autoimmune disease (AAID) - auto-immune thyroid disease (AITD) including hypo- and hyperthyroidism, celiac disease (CD), gastric autoimmunity (GAI) including pernicious anemia, vitiligo and adrenal gland insufficiency (AGI) - in patients with type 1 diabetes.

For AITD, CD, AGI and GAI, only studies published from 1999 onward were eligible, because in that period commercial kits for the measurement of antibodies became widely available $(29,30,31,32,33,34,35)$. As vitiligo is a clinical diagnosis independent of laboratory measurements, studies were eligible irrespective of the year of publication. The search strategy was drafted in collaboration with a trained librarian and is shown in the Supplementary Table 3 (see section on supplementary data given at the end of this article). Reference lists of included studies where checked for additional references. Only studies in English, Dutch, French and German were considered.

\section{Study selection}

Title and abstract of articles retrieved from the search strategy were initially screened by one reviewer $(\mathrm{C} \mathrm{N})$ for eligibility. Potentially relevant articles were read in fulltext by one reviewer ( $\mathrm{C} \mathrm{N}, \mathrm{B} \mathrm{U}$ or $\mathrm{L} \mathrm{J})$, followed by data extraction based on a predefined data extraction sheet (see Supplementary Table 4). Eligibility and extracted data were verified by a second reviewer ( $\mathrm{C} \mathrm{N}, \mathrm{B} \mathrm{U}$ or L J), and disagreement was resolved by consensus. In case of multiple studies describing the same cohort of patients, the study with the largest sample size was included, unless a smaller study included more relevant patient characteristics.

Cohort studies and cross-sectional studies that investigated prevalence or (cumulative) incidence of AAID in T1D patients were potentially eligible. Study designs (case-control studies, case series) that disable the calculation of absolute risks were not included (36). Studies excluding an unknown number of patients with the outcome of interest at baseline were also excluded, as prevalence could then not be calculated. Studies based on specific subgroups of T1D diabetes patients only, other than selected on age or gender, were excluded. In case of follow-up studies, we extracted prevalence at the end of the study period, unless loss to follow-up was considerable.

\section{Data extraction}

From included studies, we extracted prevalence of AITD, CD, gastric autoimmunity, vitiligo and adrenal gland insufficiency and/or prevalence of autoantibodies corresponding with one of above-mentioned diseases. For definition of the diseases, we relied on the criteria used by the authors of included studies. Details of definitions in use are provided in the Supplementary Table 5. Additionally, we extracted information about patient characteristics of the study populations, for example, prevalence of autoantibodies including anti-GAD, age, duration of diabetes and age at diabetes onset.

Furthermore, we registered definitions of diseases, diagnostic criteria and laboratory assays that were used in the studies (data extraction sheet, Supplementary Table 4).

\section{Quality assessment}

The present meta-analysis is based on observational studies. Risk of bias assessment was based on design elements that potentially bias the studied association between diabetes and the auto-immune diseases under study. The following elements were considered:

1. Selection of patients: selection of consecutive patients (or a random sample) of a predefined type 1 diabetes population was considered adequate. Other selection criteria are considered as intermediate or high risk of bias depending on the method. 
2. Type 1 diabetes definition: diagnosis following widely accepted criteria (e.g. $(37,38))$ or based on clinical course in combination with associated auto-antibody positivity (anti-GAD) was considered as low risk of bias. Unclear or non-standardized diagnostic criteria were considered as high risk of bias.

3. Screening for concomitant auto-immune disease: Screening at inclusion of the study or at fixed intervals (independent of the risk of outcome) is considered as low risk of bias, screening based on antibody positivity is considered as intermediate risk of bias. Screening based on clinical suspicion only is considered as high risk of bias as this will underestimate the prevalence.

4. Screening for antibodies: Screening at inclusion in the study or at fixed intervals is considered as low risk of bias, screening at random was considered as intermediate risk of bias. Screening based on clinical suspicion is considered as high risk of bias.

\section{Analysis}

The main outcome was the pooled percentage of type 1 diabetes patients with any of the studied AAIDs. Most studies provided number of patients with AAID or report percentages. Prevalence of individual studies was calculated as number of patients with the outcome divided by the total number of diabetes patients at risk. For metaanalysis we used the metaprop command as described by Nyaga et al. (39). For assessment and description of heterogeneity the $I^{2}$ statistics was used.

Meta-regression analyses were performed with an exact likelihood approach in a random-effects model to test for an association of auto-immune diseases prevalence with age and duration of diabetes (if provided) using study level summary data. Meta-regression was not performed in case of $<10$ studies.

All analyses were performed with STATA 14.0 (Stata Corp.).

\section{Results}

The initial search yielded 1515 publications, of which 885 were excluded based on title and abstract. Of the remaining articles, 380 studies were retrieved for further evaluation. The main reasons for exclusion were year of publication, inapplicable inclusion criteria for patient selection and excluding an unknown number of patients with the outcome of interest at baseline (Fig. 1). Finally, 180 studies were included.

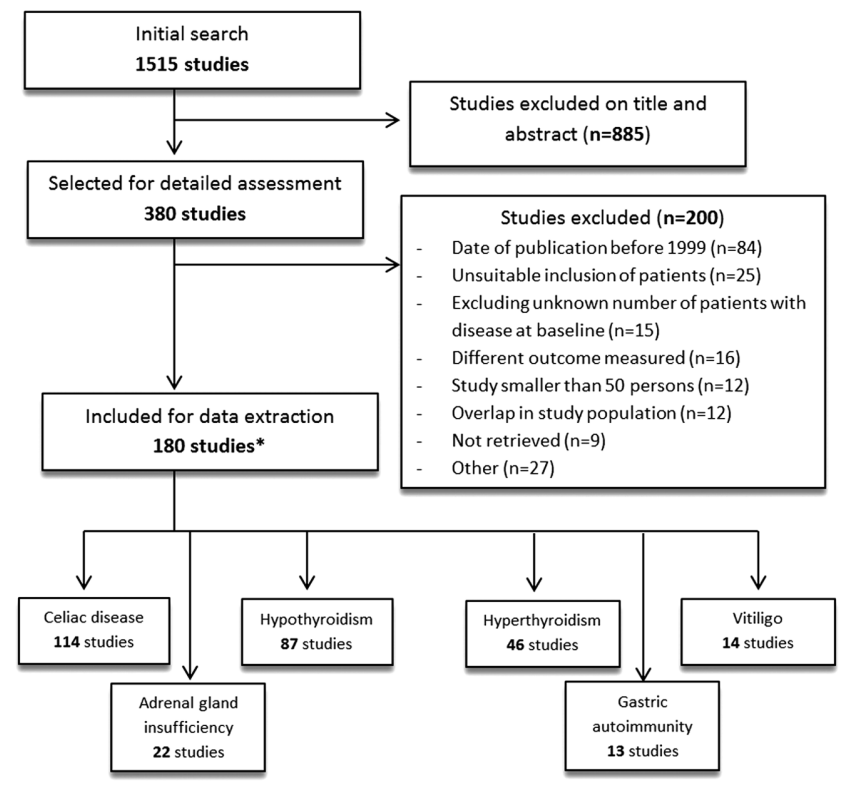

Figure 1

Flow-chart of study selection.

\section{Study characteristics}

Details of the 180 included studies are summarized in the Supplementary Table 6. Included studies were published from 1998 to 2018. From 180 studies, data about one autoimmune disease or a related antibody was extracted, and in the other studies, prevalence of more than one autoimmune disease or antibody was reported (maximum 6). The 180 studies comprised 293889 patients in total. The mean age of the study populations was 19.2 years (range 3.2 to 64.4 ) and the age at onset of diabetes was 12.2 years (range 4.4 to 53.8 ).

\section{Risk of bias assessment}

Overall, inclusion criteria and screening methods were poorly reported. Only 13 studies (7\%) reported information on all eligibility criteria. Detailed information on the risk of bias of the studies is provided in Supplementary Table 7.

\section{Prevalence of associated disease and auto-antibodies}

The number of studies that provided data for specific auto-immune conditions ranged from 87 (CD) to 8 (gastric autoimmunity) and for associated antibodies from 4 to 49 . An overview of weighted prevalence of associated diseases and auto-antibodies are shown in Table 1 . 
Table 1 Meta-analysis of auto-immune disease and related antibodies among type I diabetes patients.

\begin{tabular}{l} 
Disease of interest \\
\hline Thyroid disease \\
Celiac disease \\
insufficiency \\
Adiligo \\
Gastric autoimmunity \\
indand
\end{tabular}

\begin{tabular}{l} 
\\
\hline Hypothyroidism \\
TPO and or TG antibodies \\
TPO antibodies \\
TG antibodies \\
Hyperthyroidism \\
TSH receptor antibodies / TSI \\
Celiac disease \\
Any gluten related antibodies \\
Tissue transglutaminase \\
antibodies (IgA) \\
Tissue transglutaminase \\
antibodies (IgA/IgG) \\
Anti-endomysial antibodies (IgA) \\
Antigliadin antibodies (IgA) \\
Antigliadin antibodies (IgG) \\
Pernicious anemia \\
Anti-parietal cell antibodies \\
Vitiligo \\
Adrenal gland insufficiency \\
Anti-adrenal antibodies \\
(AAA/21-OHab)
\end{tabular}

Disease prevalence is also calculated for studies with a mean age under or over 25 years, see Supplementary Table 1. Details of relation with age or duration of diabetes in thyroid and CD are shown in Supplementary Table 2.

\section{Thyroid disease}

\section{Hypothyroidism}

In total, 65 studies reported the prevalence of hypothyroidism, which ranged from 0.6 and $44 \%$. The pooled prevalence of hypothyroidism in T1D was 9.8\% (95\% CI: 6.5-12.3, $I^{2}$ 99\%) and of clinical overt hypothyroidism 3.5\% (95\% CI: 2.0-5.2, $I^{2}$ 83\%, 13 studies) (Fig.2). Meta-regression showed that for every 10-year increase in age, the prevalence of auto-immune hypothyroidism (including subclinical disease) increases with 4.6\% (95\% CI: 2.6-6/8, P<0.000, 54 studies). Also an association with diabetes duration was found, with an increase in prevalence of $8.8 \%$ every 10 years (95\% CI: 5.4-12.2, $P<0.000,45$ studies).

\section{Hyperthyroidism}

Reported prevalence of hyperthyroidism ranged between 0.0 and 7.5\%; the weighted mean prevalence was 1.3\% (95\% CI: 0.9-1.8, $I^{2}:$ 93\%, 45 studies). Prevalence of hyperthyroidism was increasing with $0.5 \%$ with every 10-year increase of age (95\% CI: 0.1-1.0, $P 0.013,34$ studies) and with $1.3 \%$ with every 10 -year

\begin{tabular}{|c|c|c|c|}
\hline $\begin{array}{l}\text { Weighted mean } \\
\text { prevalence }(\%)\end{array}$ & $95 \% \mathrm{Cl}$ & $\begin{array}{c}\text { Studies } \\
\text { included }(n)\end{array}$ & $\begin{array}{l}\text { Reported prevalence in the } \\
\text { general population (\%) }\end{array}$ \\
\hline 9.8 & $7.5-12.3$ & 65 & $2-4.6(40,88)$ \\
\hline 18.9 & $17.2-20.6$ & 35 & Unknown \\
\hline 18.3 & $15.8-21.0$ & 53 & $11.3-12.8(40,46)$ \\
\hline 12.3 & $10.0-14.9$ & 29 & $10.4(40)$ \\
\hline 1.3 & $0.9-1.8$ & 45 & $1.0-4.0(40,65,66,67)$ \\
\hline 9.5 & $1.4-22.7$ & 4 & Unknown \\
\hline 4.7 & $4.0-5.5$ & 87 & $0.5-1.0(73,74,89)$ \\
\hline 10.2 & $8.4-12.7$ & 24 & Unknown \\
\hline 9.8 & $8.2-11.6$ & 40 & $1.5(90)$ \\
\hline 9.8 & $8.4-11.3$ & 49 & $2.1(91)$ \\
\hline 5.3 & $4.3-6.4$ & 26 & $0.8(92)$ \\
\hline 9.7 & $5.1-15.5$ & 13 & $1.6(74)$ \\
\hline 12.7 & $6.1-21.0$ & 11 & $7.1(74)$ \\
\hline 4.3 & $1.6-8.2$ & 8 & $0.2(79)$ \\
\hline 9.3 & $5.4-14.1$ & 7 & $3-10(93)$ \\
\hline 2.4 & $1.2-3.9$ & 14 & $0.4(79)$ \\
\hline 0.2 & $0.0-0.4$ & 15 & $0.012(87)$ \\
\hline 1.4 & $0.8-2.2$ & 13 & Unknown \\
\hline
\end{tabular}

increase in diabetes duration (95\% CI: 0.5-2.1, P 0.003, 27 studies).

\section{AITD-related antibodies}

Prevalence of thyroid antibodies was 18.9\% (95\% CI: 17.2-20.6, $I^{2}$ : 93\%, 35 studies) for TPO, TG or both (Fig. 3) Weighted prevalence of TPO positivity was $18.3 \%$ (95\% CI: 15.8-21.0, I²: 92\% 53 studies); TG antibody positivity 12.3\% (95\% CI: 10.0-14.9, I': 87\%, 29 studies). Meta-regression analysis showed that for every 10-year increase of age, the prevalence of TPO antibodies increased with 3.5\% (95\% CI: 1.2-5.6, P 0.002, 49 studies) and $7.0 \%$ with 10 -year increase in diabetes duration (95\% CI: 1.2-12.9, P 0.020, 42 studies). Prevalence of TG antibodies was not clearly related to age or diabetes duration. Mean prevalence of TSH receptor antibody positivity in type 1 diabetes patients was 9.5\% (95\% CI: 1.4-22.7, $I^{2}$ : 89\%, 4 studies).

\section{Celiac disease}

Including 87 studies, prevalence of $\mathrm{CD}$ ranged from 0.4 up till 13.5\%, mean 4.7\% (95\% CI: 4.0-5.5, $I^{2}$ : 97\%). The prevalence was not clearly related to age or duration of diabetes in a meta-regression. Pooled prevalence of autoantibodies varied from 5.3 to $12.7 \%$ depending on the type of antibody (Table 1). Meta-regression analysis showed that for every 10-year increase of age, the prevalence of 


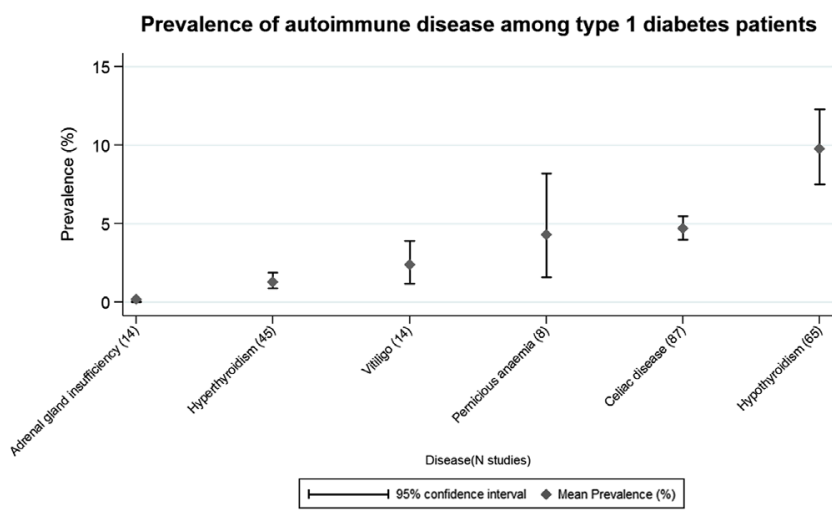

Figure 2

Overview of mean prevalence of auto-immune disease among type 1 diabetes patients.

any CD-associated antibody positivity increased with age and diabetes duration $(6.8 \%, 95 \%$ CI: $0.2-13.3, P 0.043$, 19 studies and 1.5\%, 95\% CI: -0.1, 30.7, P 0.051, 16 studies). However, prevalence varied depending on the type of antibody. Anti-endomysial antibody positivity decreased with $1.0 \%$ with 10 years of age (95\% CI: -1.8 to $-0.2, P 0.01,24$ studies) and prevalence of antigliadin antibodies ( $\operatorname{Ig} \mathrm{A})$ increased with diabetes duration $(14.4 \%$ in 10 years, 1.4, 27.4, 10 studies). Prevalence of tissue transglutaminase antibodies was stable across age ranges.

\section{Gastric autoimmunity}

Mean prevalence of pernicious anemia was 4.3\% (95\% CI: 1.6-8.2, $I^{2}$ : 93\%, 8 studies). Anti-parietal cell antibodies were prevalent in $9.3 \%$ of the patients (95\% CI: $5.4-14.1$, $\mathrm{I}^{2}$ : 94\%, 7 studies).

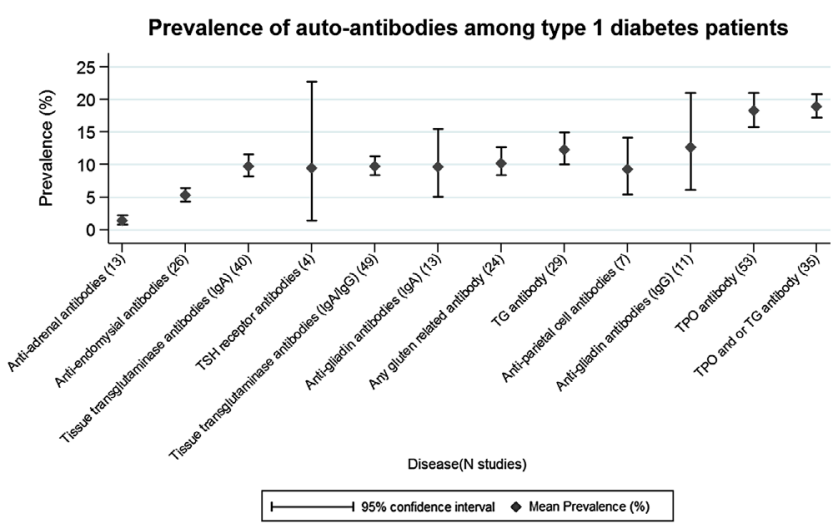

Figure 3

Overview of mean prevalence of auto-immune disease related antibodies among type 1 diabetes patients.

\section{Vitiligo}

Prevalence of vitiligo ranged from 0.5 to $23.3 \%$ and was found in 2.4\% (95\% CI: 1.2-3.9, $I^{2}$ : 88\%, 14 studies).

\section{Adrenal gland insufficiency}

Adrenal gland insufficiency was prevalent in $0-4 \%$ of the population (14 studies) with a mean prevalence of 0.2\% (95\% CI: 0.0-0.4, $\left.I^{2}: 43 \%\right)$. Mean prevalence of antiadrenal antibody positivity in type 1 diabetes patients was $1.4 \%$ (95\% CI: 0.8-2.2, $I^{2}$ : 66\%, 13 studies), with no relation with age.

\section{Discussion}

This meta-analysis provides a broad overview of concomitant auto-immune disease in type 1 diabetes patients. We found an increased prevalence for most of the diseases investigated compared to the general population and an increasing prevalence with age in thyroid disease (Table 1). The apparent lack of association between age and other auto-immune diseases may be due to a lack of power of an analysis at the study level. Individual patient data analysis may provide more insight in the association with age.

\section{Thyroid disease}

\section{Hypothyroidism}

In our study, we found a prevalence of hypothyroidism among type 1 diabetes patients twice as high as the general population (9.8 vs 4.6\% (40)). Reported prevalence ranged from 0.6 to $44 \%$, depending on the age of the study population. Also a geographical distribution may translate into prevalence differences, with an average higher prevalence in the southeast of Europe and some parts of Asia (41, 42, 43, 44, 45).

The prevalence of TPO antibodies is also higher among type 1 diabetes patients, 18.9 vs reported prevalence in the general population of $11.3-12.8 \%(40,46)$, in contrast to TG antibodies, with a similar prevalence (12.3 vs 10.4 (40)). This suggests that TPO antibodies are more specific and more frequently present in patients with AITD (47).

Differences in reported prevalence between study populations may partly be explained by the mean age of the study population, as the prevalence is higher at older age (Supplementary Table 1). Although there is a high variability between diagnostic criteria used, laboratory 
measurements and reference values for antibodies, possibly explains another part of the heterogeneity between studies. For example, reference values for TSH indicating (auto-immune) hypothyroidism varied from $>4.0$ up to $>10 \mathrm{mU} / \mathrm{L}(48,49,50,51)$, usually but not always $(49,51,52)$ dependent on fT 4 levels to determine if the condition was classified as clinical overt or subclinical disease. In most studies, only hypothyroid patients with antibody positivity were considered as having autoimmune hypothyroidism $(9,41,44,53,54,55,56,57)$ and others included ultrasound to confirm the diagnosis (58) or both $(59,60,61,62,63)$. Two studies counted cases that were treated for their thyroid disease irrespective of antibodies $(12,64)$. In ten studies, no information was given on diagnostic criteria at all. Because the prevalence is not always estimated based on antibody positivity, overall prevalence in this meta-analysis is probably slightly overestimated because patients with hypothyroidism other than auto-immune-mediated disease are included in some of the studies.

\section{Hyperthyroidism}

We found a prevalence of $1.3 \%$ for hyperthyroidism, which is comparable to the general population, as reported prevalence ranges from 1 to $4 \%(40,65,66,67)$ Three studies reported a notable high prevalence $(10,68$, 69 ) of hyperthyroidism. One of these studies reported age at onset of diabetes, which was remarkably high (26 years) (70). This is in line with previously published studies that showed a higher age at onset of diabetes in patients with concomitant Graves' disease $(71,72)$.

It has been shown that the prevalence of hyperthyroidism is depending on the age and sex of the population (65) and more prevalent in woman and older age (71). In this study, we found a mean prevalence of $1.34 \%$ percent in woman vs $0.9 \%$ in men, although this difference was not significant.

Whereas the prevalence of hyperthyroidism was low, the pooled prevalence of TRAb positivity was approximately seven-fold higher than the disease prevalence $(9.5 \%)$, meaning that antibody positivity does not implicate clinical overt disease in the majority of cases.

\section{Celiac disease}

In our study, the mean prevalence of CD in type 1 diabetes patients was 4.5 to 9-fold higher than that in the general population $(73,74)$. The reported prevalence was highly depending on diagnostic criteria and intensity of screening. Taking into account patients with active disease only, the pooled prevalence is $4.0 \%$.

Most studies determined the indication for duodenal biopsy based on antibody positivity (58/87 studies, 67\%), but various antibodies were used as reference, and as a consequence, the proportion of patients screened with biopsies varied from 0.7 to $100 \%$. The percentage of patients diagnosed with $\mathrm{CD}$ increased if more patients underwent a biopsy. Studies that diagnosed CD in all the patients who underwent duodenal biopsy found a mean prevalence of 4.9\% (95\% CI: 3.4-6.7, 14 studies). These numbers may indicate that accuracy in diagnosis of CD and thereby the magnitude of the celiac iceberg (75) depends on criteria used to select patients for biopsy. Some studies suggest that CD precedes other auto-immune disease, in particular T1D, by increasing gut permeability for gluten $(76,77)$, which would implicate that $C D$ is mainly established before the diagnoses of T1D and not increasing thereafter. This hypothesis would be supported by previous studies concluding that in half the patients CD is diagnosed within 2 years of T1D diagnosis (78). In our study, any relation with age or diabetes duration would be difficult to demonstrate, as we did not have individual patient data.

\section{Gastric autoimmunity}

In this meta-analysis prevalence of parietal cell antibodies was around a twofold higher than the general population, but anemia as a consequence of vitamin B12 deficiency was twenty times more common than usual. This possible discrepancy may be caused by other (non-auto-immune) factors such as comorbidity or metformin use. However, it does confirm the need for regular screening for anemia and vitamin B12 deficiency.

\section{Vitiligo}

In our analysis, 13 studies reported prevalence of vitiligo in type 1 diabetes patients. The mean prevalence was 2.4 vs $0.4 \%$ in the general population (79). Vitiligo was often registered as secondary finding and screening methods were usually undisclosed $(17,72,80)$. This may lead to an underestimation of the prevalence. In studies that screened specifically on AAID, cutaneous manifestations or vitiligo $(16,81,82,83,84)$ in diabetes patients estimated prevalence was higher, 4.3 vs $1.4 \%$, compared to studies that were not actively screening. Vitiligo therefore, may be a common missed diagnosis in many patients with 
type 1 diabetes as it has limited clinical consequences and therefore active screening is frequently absent.

\section{Adrenal gland insufficiency}

Auto-immune adrenal gland insufficiency (Addison's disease) is a serious disease, caused by the loss of adrenal function and impaired cortisol production. The most serious and potential lethal manifestation of adrenal insufficiency is shock during a crisis, but it also complicates management of diabetes with increased risk for hypoglycemia or disturbances in the potassium regulation $(85,86)$. Although in this study the prevalence of adrenal gland insufficiency was low, only $0.2 \%$, this is higher than that in the general population, namely 0.012\% (87). Considering the implications concomitant Addison's disease has for T1D patients, this is an important risk to consider.

\section{Toward a screening policy for auto-immune disease in type 1 diabetes}

Type 1 diabetes patients are at increased risk for hypothyroidism, CD, pernicious anemia, vitiligo and Addison's disease. Clearly, in the presence of symptoms of any of the auto-immune conditions mentioned, there should be no threshold to test given the increased risk. It is however less obvious whether a screening policy should routinely be implemented in non-symptomatic patients, even though the number needed to screen for the most prevalent condition (thyroid disease) is approximately 100 (71) and for some of the diseases the prevalence increases substantially with age. If more conditions are included in a screening policy, (for example bi-annually) the yield of screening will increase. An important consideration is that some of the conditions have clinical consequences and that concomitant auto-immune disease can be relevant in diabetes regulation. The ultimate decision on screening however requires careful balancing of costs, burden and yield.

\section{Conclusion}

The prevalence of auto-immune hypothyroidism, CD, adrenal gland insufficiency, vitiligo and gastric autoimmunity is higher in type 1 diabetes patients. Concomitant auto-immune disease can complicate diabetes management and has various clinical presentations. For this reason, the need for adequate screening protocols seems obvious. The ultimate decision on optimal screening policy remains obscure.

\section{Supplementary data}

This is linked to the online version of the paper at https://doi.org/10.1530/ EJE-18-0515.

\section{Declaration of interest}

O M Dekkers is a methodological editor of the journal, but was not involved in the review process of this article. The other authors declare that there is no conflict of interest that could be perceived as prejudicing the impartiality of this study.

\section{Funding}

This study was funded by a grant from the $\mathrm{MCH}$ research fund $(\mathrm{MCH}$ wetenschapsbeurs 2014).

\section{Author contribution statement}

Study concept and design: C Nederstigt, O M Dekkers. Acquisition of the data: C Nederstigt, L G M Janssen, B S Uitbeijerse. Analysis and interpretation of the data: C Nederstigt, L G M Janssen, B S Uitbeijerse. Drafting of the manuscript: C Nederstigt, O M Dekkers. Critical revision of the manuscript for important intellectual content: O M Dekkers, $E$ P M Corssmit, L G M Janssen, B S Uitbeijerse, E J P de Koning. Statistical analysis: C Nederstigt, O M Dekkers. Obtained funding: C Nederstigt. Study supervision: O M Dekkers.

\section{References}

1 Wicker LS, Clark J, Fraser HI, Garner VES, Gonzalez-Munoz A, Healy B, Howlett S, Hunter K, Rainbow D, Rosa RL et al. Type 1 diabetes genes and pathways shared by humans and NOD mice. Journal of Autoimmunity 200525 29-33. (https://doi.org/10.1016/j. jaut.2005.09.009)

2 Boldison J \& Wong FS. Immune and pancreatic beta cell interactions in type 1 diabetes. Trends in Endocrinology and Metabolism 201627 856-867. (https://doi.org/10.1016/j.tem.2016.08.007)

3 Sosinowski T \& Eisenbarth GS. Type 1 diabetes: primary antigen/ peptide/register/trimolecular complex. Immunologic Research 201355 270-276. (https://doi.org/10.1007/s12026-012-8367-6)

4 Lu MC, Chang SC, Huang KY, Koo M \& Lai NS. Higher risk of thyroid disorders in young patients with Type 1 diabetes: a 12-year nationwide, population-based, retrospective cohort study. PLOS ONE 201611 e0152168. (https://doi.org/10.1371/journal.pone.0152168)

5 Kylokas A, Kaukinen K, Huhtala H, Collin P, Maki M \& Kurppa K. Type 1 and type 2 diabetes in celiac disease: prevalence and effect on clinical and histological presentation. BMC Gastroenterology 201616 76. (https://doi.org/10.1186/s12876-016-0488-2)

6 Rubio-Tapia A, Hill ID, Kelly CP, Calderwood AH \& Murray JA. ACG clinical guidelines: diagnosis and management of celiac disease. American Journal of Gastroenterology 2013108 656-676; quiz 656-676. (https://doi.org/10.1038/ajg.2013.79)

7 Umpierrez GE, Latif KA, Murphy MB, Lambeth HC, Stentz F, Bush A \& Kitabchi AE. Thyroid dysfunction in patients with type 1 diabetes: a longitudinal study. Diabetes Care 200326 1181-1185. (https://doi. org/10.2337/diacare.26.4.1181)

8 Glastras SJ, Craig ME, Verge CF, Chan AK, Cusumano JM \& Donaghue KC. The role of autoimmunity at diagnosis of type 1 diabetes in the development of thyroid and celiac disease and 
microvascular complications. Diabetes Care 200528 2170-2175. (https://doi.org/10.2337/diacare.28.9.2170)

9 Triolo TM, Armstrong TK, McFann K, Yu L, Rewers MJ, Klingensmith GJ, Eisenbarth GS \& Barker JM. Additional autoimmune disease found in $33 \%$ of patients at type 1 diabetes onset. Diabetes Care 201134 1211-1213. (https://doi.org/10.2337/ dc10-1756)

10 Hunger-Battefeld W, Fath K, Mandecka A, Kiehntopf M, Kloos C, Muller UA \& Wolf G. [Prevalence of polyglandular autoimmune syndrome in patients with diabetes mellitus type 1]. Medizinische Klinik 2009104 183-191. (https://doi.org/10.1007/s00063-0091030-x)

11 Ben-Skowronek I, Michalczyk A, Piekarski R, Wysocka-Lukasik B $\&$ Banecka B. Type III Polyglandular Autoimmune Syndromes in children with type 1 diabetes mellitus. Annals of Agricultural and Environmental Medicine 201320 140-146.

12 De Block CEM, De Leeuw IH, Decochez K, Winnock F, Van Autreve J, Van Campenhout CM, Martin M \& Gorus FK. The presence of thyrogastric antibodies in first degree relatives of type 1 diabetic patients is associated with age and proband antibody status. Journal of Clinical Endocrinology and Metabolism 200186 4358-4363. (https:// doi.org/10.1210/jcem.86.9.7833)

13 De Block CEM, De Leeuw IH, Vertommen JJF, Rooman RPA, Du Caju MVL, Van Campenhout CM, Weyler JJ, Winnock F, Van Autreve J \& Gorus FK. Beta-cell, thyroid, gastric, adrenal and coeliac autoimmunity and HLA-DQ types in type 1 diabetes. Clinical and Experimental Immunology 2001126 236-241. (https://doi. org/10.1046/j.1365-2249.2001.01668.x)

14 Buschur E, Sarma AV, Pietropaolo M, Dunn RL, Braffett BH, Cleary PA, Cowie C, Larkin ME, Wessells H, Nathan DM \& Kim C. Self-reported autoimmune disease by sex in the diabetes control and complications trial/epidemiology of diabetes interventions and complications (dcct/edic) study. Diabetes Care 201437 e28-e29. (https://doi.org/10.2337/dc13-1890)

15 Cev EZ, Pascu O, Serban V, Mulder CJJ, Taban S \& Samasca G. The prevalence of celiac disease in adult and adolescent Romanian patients with type 1 diabetes mellitus. Timisoara Medical Journal 2010 60 189-195.

16 Verma GC, Subhash JC, Shantanu V, Manoj S, Nyati A, Hardeva RN $\&$ Hariom M. Prevalence of cutaneous manifestations of diabetes mellitus. IOSR Journal of Dental and Medical Sciences 201311 41-47. (https://doi.org/10.9790/0853-1164147)

17 Lupi I, Raffaelli V, Di Cianni G, Caturegli P, Manetti L, Ciccarone AM, Bogazzi F, Mariotti S, Del Prato S \& Martino E. Pituitary autoimmunity in patients with diabetes mellitus and other endocrine disorders. Journal of Endocrinological Investigation 201336 127-131. (https://doi.org/10.1007/BF03346747)

18 Holl RW, Bohm B, Loos U, Grabert M, Heinze E \& Homoki J. Thyroid autoimmunity in children and adolescents with type 1 diabetes mellitus. Effect of age, gender and HLA type. Hormone Research 1999 52 113-118. (https://doi.org/10.1159/000023446)

19 Golden B, Levin L, Ban Y, Concepcion E, Greenberg DA \& Tomer Y. Genetic analysis of families with autoimmune diabetes and thyroiditis: evidence for common and unique genes. Journal of Clinical Endocrinology and Metabolism 200590 4904-4911. (https:// doi.org/10.1210/jc.2004-2236)

20 Menconi F, Osman R, Monti MC, Greenberg DA, Concepcion ES $\&$ Tomer Y. Shared molecular amino acid signature in the HLA-DR peptide binding pocket predisposes to both autoimmune diabetes and thyroiditis. PNAS 2010107 16899-16903. (https://doi. org/10.1073/pnas.1009511107)

21 Menconi F, Monti MC, Greenberg DA, Oashi T, Osman R, Davies TF, Ban Y, Jacobson EM, Concepcion ES, Li CW et al. Molecular amino acid signatures in the MHC class II peptide-binding pocket predispose to autoimmune thyroiditis in humans and in mice. PNAS 2008105 14034-14039. (https://doi.org/10.1073/pnas.0806584105)
22 Ikegami H, Awata T, Kawasaki E, Kobayashi T, Maruyama T, Nakanishi K, Shimada A, Amemiya S, Kawabata Y, Kurihara S et al. The association of CTLA4 polymorphism with type 1 diabetes is concentrated in patients complicated with autoimmune thyroid disease: a multicenter collaborative study in Japan. Journal of Clinical Endocrinology and Metabolism 200691 1087-1092. (https://doi. org/10.1210/jc.2005-1407)

23 Hage M, Zantout MS \& Azar ST. Thyroid disorders and diabetes mellitus. Journal of Thyroid Research 20112011 439463. (https://doi. org/10.4061/2011/439463)

24 Khoury N, Semenkovich K \& Arbelaez AM. Coeliac disease presenting as severe hypoglycaemia in youth with type 1 diabetes. Diabetic Medicine 201431 e33-e36. (https://doi.org/10.1111/dme.12488)

25 Erickson QL, Faleski EJ, Koops MK \& Elston DM. Addison's disease: the potentially life-threatening tan. Cutis $20006672-74$.

26 Dewar DH \& Ciclitira PJ. Clinical features and diagnosis of celiac disease. Gastroenterology 2005128 S19-S24. (https://doi. org/10.1053/j.gastro.2005.02.010)

27 Maratou E, Hadjidakis DJ, Kollias A, Tsegka K, Peppa M, Alevizaki M, Mitrou P, Lambadiari V, Boutati E, Nikzas D et al. Studies of insulin resistance in patients with clinical and subclinical hypothyroidism. European Journal of Endocrinology 2009160 785-790. (https://doi. org/10.1530/EJE-08-0797)

28 Bakker SF, Pouwer F, Tushuizen ME, Hoogma RP, Mulder CJ \& Simsek S. Compromised quality of life in patients with both type 1 diabetes mellitus and coeliac disease. Diabetic Medicine 201330 835-839. (https://doi.org/10.1111/dme.12205)

29 Engler H, Riesen WF \& Keller B. Anti-thyroid peroxidase (anti-TPO) antibodies in thyroid diseases, non-thyroidal illness and controls. Clinical validity of a new commercial method for detection of antiTPO (thyroid microsomal) autoantibodies. Clinica Chimica Acta 1994 225 123-136. (https://doi.org/10.1016/0009-8981(94)90040-X)

30 Dieterich W, Laag E, Schopper H, Volta U, Ferguson A, Gillett H, Riecken EO \& Schuppan D. Autoantibodies to tissue transglutaminase as predictors of celiac disease. Gastroenterology 1998 115 1317-1321. (https://doi.org/10.1016/S0016-5085(98)70007-1)

31 Miller A, Paspaliaris W, Elliott PR \& d'Apice A. Antitransglutaminase antibodies and coeliac disease. Australian and New Zealand Journal of Medicine 199929 239-242. (https://doi. org/10.1111/j.1445-5994.1999.tb00690.x)

32 Costagliola S, Morgenthaler NG, Hoermann R, Badenhoop K, Struck J, Freitag D, Poertl S, Weglohner W, Hollidt JM, Quadbeck B et al. Second generation assay for thyrotropin receptor antibodies has superior diagnostic sensitivity for Graves' disease. Journal of Clinical Endocrinology and Metabolism 199984 90-97. (https://doi. org/10.1210/jcem.84.1.5415)

33 Pedersen IB, Knudsen N, Perrild H, Ovesen L \& Laurberg P. TSH-receptor antibody measurement for differentiation of hyperthyroidism into Graves' disease and multinodular toxic goitre: a comparison of two competitive binding assays. Clinical Endocrinology 200155 381-390. (https://doi.org/10.1046/j.13652265.2001.01347.x)

34 Kordonouri O, Dieterich W, Schuppan D, Webert G, Muller C, Sarioglu N, Becker M \& Danne T. Autoantibodies to tissue transglutaminase are sensitive serological parameters for detecting silent coeliac disease in patients with type 1 diabetes mellitus. Diabetic Medicine 200017 441-444. (https://doi.org/10.1046/j.14645491.2000.00291.x)

35 Laureti S, Aubourg P, Calcinaro F, Rocchiccioli F, Casucci G, Angeletti G, Brunetti P, Lernmark A, Santeusanio F \& Falorni A. Etiological diagnosis of primary adrenal insufficiency using an original flowchart of immune and biochemical markers. Journal of Clinical Endocrinology and Metabolism 199883 3163-3168. (https:// doi.org/10.1210/jcem.83.9.5103)

36 Dekkers OM, Egger M, Altman DG \& Vandenbroucke JP. Distinguishing case series from cohort studies. Annals of Internal 
Medicine 2012156 37-40. (https://doi.org/10.7326/0003-4819-156-1201201030-00006)

37 Craig ME, Jefferies C, Dabelea D, Balde N, Seth A \& Donaghue KC. Definition, epidemiology, and classification of diabetes in children and adolescents. Pediatric Diabetes 201415 (Supplement 20) 4-17. (https://doi.org/10.1111/pedi.12186)

38 Diagnosis and classification of diabetes mellitus. Diabetes Care 2010 33 (Supplement 1) S62-S69. (https://doi.org/10.2337/dc10-S062)

39 Nyaga VN, Arbyn M \& Aerts M. Metaprop: a Stata command to perform meta-analysis of binomial data. Archives of Public Health 201472 39. (https://doi.org/10.1186/2049-3258-72-39)

40 Hollowell JG, Staehling NW, Flanders WD, Hannon WH, Gunter EW, Spencer CA \& Braverman LE. Serum TSH, T(4), and thyroid antibodies in the United States population (1988 to 1994): National Health and Nutrition Examination Survey (NHANES III). Journal of Clinical Endocrinology and Metabolism 200287 489-499. (https://doi. org/10.1210/jcem.87.2.8182)

41 Goswami R, Marwaha RK, Goswami D, Gupta N, Ray D, Tomar N \& Singh S. Prevalence of thyroid autoimmunity in sporadic idiopathic hypoparathyroidism in comparison to type 1 diabetes and premature ovarian failure. Journal of Clinical Endocrinology and Metabolism 2006 91 4256-4259. (https://doi.org/10.1210/jc.2006-1005)

42 Unnikrishnan AG, Kumaravel V, Nair V, Rao A, Jayakumar RV, Kumar H \& Sanjeevi CB. TSH receptor antibodies in subjects with type 1 diabetes mellitus. Annals of the New York Academy of Sciences 20061079 220-225. (https://doi.org/10.1196/annals.1375.034)

43 Snajderova M, Martinek J, Horejsi J, Novakova D, Lebl J \& Kolouskova S. Premenarchal and postmenarchal girls with insulindependent diabetes mellitus: ovarian and other organ-specific autoantibodies, menstrual cycle. Journal of Pediatric and Adolescent Gynecology 199912 209-214. (https://doi.org/10.1016/S10833188(99)00023-6)

44 Prazny M, Skrha J, Limanova Z, Vanickova Z, Hilgertova J, Prazna J, Jaresova M \& Striz I. Screening for associated autoimmunity in type 1 diabetes mellitus with respect to diabetes control. Physiological Research $2005 \mathbf{5 4} 41-48$.

45 Vondra K, Vrbikova J, Sterzl I, Bilek R, Vondrova M \& Zamrazil V. Thyroid autoantibodies and their clinical relevance in young adults with type 1 diabetes during the first $12 \mathrm{yr}$ after diabetes onset. Journal of Endocrinological Investigation 200427 728-732. (https://doi. org/10.1007/BF03347513)

46 Amouzegar A, Gharibzadeh S, Kazemian E, Mehran L, Tohidi M \& Azizi F. The prevalence, incidence and natural course of positive Antithyroperoxidase antibodies in a population-based study: Tehran Thyroid Study. PLoS ONE 201712 e0169283. (https://doi. org/10.1371/journal.pone.0169283)

47 Singer PA, Cooper DS, Levy EG, Ladenson PW, Braverman LE, Daniels G, Greenspan FS, McDougall IR \& Nikolai TF. Treatment guidelines for patients with hyperthyroidism and hypothyroidism. Standards of Care Committee, American Thyroid Association. JAMA 1995273 808-812. (https://doi.org/10.1001/ jama.1995.03520340064038)

48 Jonsdottir B, Andersson C, Carlsson A, Delli A, Forsander G, Ludvigsson J, Marcus C, Samuelsson U, Ortqvist E, Lernmark ^ et al. Thyroid autoimmunity in relation to islet autoantibodies and HLA-DQ genotype in newly diagnosed type 1 diabetes in children and adolescents. Diabetologia 201356 1735-1742. (https://doi. org/10.1007/s00125-013-2934-9)

49 Faesch S, Jennane F, Izembart I, Chatenoud L, Taupin P, Martin D, Polak M \& Robert J-J. [Thyroiditis and gluten intolerance: extrapancreatic auto-immune diseases associated with type 1 diabetes]. Archives de Pédiatrie 200714 24-30. (https://doi. org/10.1016/j.arcped.2006.09.025)

50 Hansen D, Bennedbaek FN, Hoier-Madsen M, Hegedus L \& Jacobsen BB. A prospective study of thyroid function, morphology and autoimmunity in young patients with type 1 diabetes. European
Journal of Endocrinology 2003148 245-251. (https://doi.org/10.1530/ eje.0.1480245)

51 Muhame RM, Mworozi EA, McAssey K \& Lubega I. Thyroid autoimmunity and function among Ugandan children and adolescents with type-1 diabetes mellitus. Pan African Medical Journal 201419 137. (https://doi.org/10.11604/ pamj.2014.19.137.5115)

52 Bilimoria KY, Pescovitz OH \& DiMeglio LA. Autoimmune thyroid dysfunction in children with type 1 diabetes mellitus: screening guidelines based on a retrospective analysis. Journal of Pediatric Endocrinology and Metabolism 200316 1111-1117.

53 Karavanaki K, Kakleas K, Paschali E, Kefalas N, Konstantopoulos I, Petrou V, Kanariou M \& Karayianni C. Screening for associated autoimmunity in children and adolescents with type 1 diabetes mellitus (T1DM). Hormone Research in Paediatrics 200971 201-206. (https://doi.org/10.1159/000201108)

54 Park YS, Kim TW, Kim WB \& Cho BY. Increased prevalence of autoimmune thyroid disease in patients with type 1 diabetes. Korean Journal of Internal Medicine 200015 202-210. (https://doi. org $/ 10.3904 / \mathrm{kjim} .2000 .15 .3 .202)$

55 Riquetto ADC, de Noronha RM, Matsuo EM, Ishida EJ, Vaidergorn RE, Soares Filho MD \& Calliari LEP. Thyroid function and autoimmunity in children and adolescents with type 1 diabetes mellitus. Diabetes Research and Clinical Practice 2015110 e9-e11. (https://doi.org/10.1016/j.diabres.2015.07.003)

56 Shiva S \& Behbahan AG. Autoimmune thyroid disease in children and adolescents with type 1 diabetes mellitus in Northwest Iran. Saudi Medical Journal 200930 673-676.

57 Ardestani SK, Keshteli AH, Khalili N, Hashemipour M \& Barekatain R. Thyroid disorders in children and adolescents with type 1 diabetes mellitus in Isfahan, Iran. Iranian Journal of Pediatrics 201121 502-508.

58 Severinski S, Banac S, Severinski NS, Ahel V \& Cvijovic K. Epidemiology and clinical characteristics of thyroid dysfunction in children and adolescents with type 1 diabetes. Collegium Antropologicum 200933 273-279.

59 Benvenga S, Pintaudi B, Vita R, Di Vieste G \& Di Benedetto A. Serum thyroid hormone autoantibodies in type 1 diabetes mellitus. Journal of Clinical Endocrinology and Metabolism 2015100 1870-1878. (https://doi.org/10.1210/jc.2014-3950)

60 Franzese A, Buono P, Mascolo M, Leo AL \& Valerio G. Thyroid autoimmunity starting during the course of type 1 diabetes denotes a subgroup of children with more severe diabetes. Diabetes Care 2000 23 1201-1202. (https://doi.org/10.2337/diacare.23.8.1201)

61 Mohamed SN, Hussien MO, Hussein AEME, Mohamed IN \& Abdullah MA. The prevalence of thyroid peroxidase auto-antibodies in Sudanese children with type 1 diabetes mellitus. Khartoum Medical Journal $20103381-384$.

62 Noelle V, Raile K, Schmidt H \& Schwarz HP. Autoimmune thyroiditis in children and adolescents with type 1 diabetes. Clinical presentation and suggestion for sensible and cost-efficient screening. [German]. Monatsschrift Kinderheilkunde 2002150 619-624. (https:// doi.org/10.1007/s00112-001-0343-5)

63 Simsek DG, Aycan Z, Ozen S, Cetinkaya S, Kara C, Abali S, Demir K, Tunc O, Ucakturk A, Asar G et al. Diabetes care, glycemic control, complications, and concomitant autoimmune diseases in children with type 1 diabetes in Turkey: a multicenter study. Journal of Clinical Research in Pediatric Endocrinology 20135 20-26. (https://doi. org/10.4274/Jcrpe.893)

64 Lenzi L, Mirri S, Generoso M, Guasti M, Barni F, Pepe R, Nanni L \& Toni S. Thyroid autoimmunity and type 1 diabetes in children and adolescents: screening data from Juvenile Diabetes Tuscany Regional Centre. Acta Biologica et Medica 200980 203-206.

65 Vanderpump MPJ. The epidemiology of thyroid disease. British Medical Bulletin 201199 39-51. (https://doi.org/10.1093/bmb/ ldr030) 
66 Canaris GJ, Manowitz NR, Mayor G \& Ridgway EC. The Colorado thyroid disease prevalence study. Archives of Internal Medicine 2000 160 526-534. (https://doi.org/10.1001/archinte.160.4.526)

67 Gussekloo J, van Exel E, de Craen AJ, Meinders AE, Frolich M \& Westendorp RG. Thyroid status, disability and cognitive function, and survival in old age. JAMA 2004292 2591-2599. (https://doi. org/10.1001/jama.292.21.2591)

68 Gul K, Ustun I, Aydin Y, Berker D, Erol HK, Unal M, Barazi AO, Delibasi T \& Guler S. Autoimmune thyroid disease in patients with anti-GAD positive type 1 diabetes mellitus. Open Medicine 20094 415-422. (https://doi.org/10.2478/s11536-009-0080-z)

69 Abosmaha EA, Almsahli SE, Alsabri SG, Mohamed SS \& Gebreil M. Coexistence of autoimmune disease with type I diabetes mellitus in Libyan patients. International Journal of Pharmacy and Pharmaceutical Sciences 20146 120-124.

70 Variation and trends in incidence of childhood diabetes in Europe. EURODIAB ACE Study Group. Lancet 2000355 873-876.

71 Nederstigt C, Corssmit EPM, de Koning EJP \& Dekkers OM. Incidence and prevalence of thyroid dysfunction in type 1 diabetes. Journal of Diabetes and Its Complications 201630 420-425. (https://doi. org/10.1016/j.jdiacomp.2015.12.027)

72 Greco D, Pisciotta M, Gambina F \& Maggio F. Graves' disease in subjects with type 1 diabetes mellitus: a prevalence study in western Sicily (Italy). Primary Care Diabetes 20115 241-244. (https://doi. org/10.1016/j.pcd.2011.06.001)

73 Kang JY, Kang AHY, Green A, Gwee KA \& Ho KY. Systematic review: worldwide variation in the frequency of coeliac disease and changes over time. Alimentary Pharmacology and Therapeutics 201338 226-245. (https://doi.org/10.1111/apt.12373)

74 Catassi C, Fabiani E, Ratsch IM, Coppa GV, Giorgi PL, Pierdomenico R, Alessandrini S, Iwanejko G, Domenici R, Mei E et al. The coeliac iceberg in Italy. A multicentre antigliadin antibodies screening for coeliac disease in school-age subjects. Acta Paediatrica: Supplement 1996412 29-35. (https://doi. org/10.1111/j.1651-2227.1996.tb14244.x)

75 Costa GR, Cerqueira MJ, Fernando AR, Andre Nunes JC, Auxiliadora Carvalho RM, Edinilma Felinto BM, Laissa Oliveira NA, Marques MC $\&$ De Sousa MH. The celiac iceberg: from the clinical spectrum to serology and histopathology in children and adolescents with type 1 diabetes mellitus and Down syndrome. Scandinavian Journal of Gastroenterology 201651 178-185. (https://doi.org/10.3109/0036552 1.2015.1079645)

76 Frisk G, Hansson T, Dahlbom I \& Tuvemo T. A unifying hypothesis on the development of type 1 diabetes and celiac disease: gluten consumption may be a shared causative factor. Medical Hypotheses 200870 1207-1209. (https://doi.org/10.1016/j.mehy.2007.05.058)

77 Antvorskov JC, Josefsen K, Engkilde K, Funda DP \& Buschard K. Dietary gluten and the development of type 1 diabetes. Diabetologia 201457 1770-1780. (https://doi.org/10.1007/s00125-014-3265-1)

78 Pham-Short A, Donaghue KC, Ambler G, Phelan H, Twigg S \& Craig ME. Screening for celiac disease in Type 1 diabetes: a systematic review. Pediatrics 2015136 e170-e176. (https://doi.org/10.1542/ peds.2014-2883)

79 Cooper GS \& Stroehla BC. The epidemiology of autoimmune diseases. Autoimmunity Reviews 20032 119-125. (https://doi. org/10.1016/S1568-9972(03)00006-5)
80 Buysschaert M, Tomasi JP \& Hermans MP. Prospective screening for biopsy proven coeliac disease, autoimmunity and malabsorption markers in Belgian subjects with Type 1 diabetes. Diabetic Medicine 200522 889-892. (https://doi.org/10.1111/j.14645491.2005.01542.x)

81 Ahmed K, Muhammad Z \& Qayum I. Prevalence of cutaneous manifestations of diabetes mellitus. Journal of Ayub Medical College, Abbottabad 200921 76-79.

82 Sawatkar GU, Kanwar AJ, Dogra S, Bhadada SK \& Dayal D. Spectrum of cutaneous manifestations of type 1 diabetes mellitus in 500 South Asian patients. British Journal of Dermatology 2014171 1402-1406. (https://doi.org/10.1111/bjd.13077)

83 Romano G, Moretti G, Di Benedetto A, Giofrè C, Di Cesare E, Russo G, Califano L \& Cucinotta D. Skin lesions in diabetes mellitus: prevalence and clinical correlations. Diabetes Research and Clinical Practice 199839 101-106. (https://doi.org/10.1016/S01688227(97)00119-8)

84 Pavlovic MD, Milenkovic T, Dinic M, Misovic M, Dakovic D, Todorovic S, Dakovic Z, Zecevi RD \& Doder R. The prevalence of cutaneous manifestations in young patients with type 1 diabetes. Diabetes Care 200730 1964-1967. (https://doi.org/10.2337/dc070267)

85 McAulay V \& Frier BM. Addison's disease in type 1 diabetes presenting with recurrent hypoglycaemia. Postgraduate Medical Journal 200076 230-232. (https://doi.org/10.1136/ pmj.76.894.230)

86 Harvey TC. Addison's disease and the regulation of potassium: the role of insulin and aldosterone. Medical Hypotheses 200769 1120-1126. (https://doi.org/10.1016/j.mehy.2007.02.023)

87 Laureti S, Vecchi L, Santeusanio F \& Falorni A. Is the prevalence of Addison's disease underestimated? Journal of Clinical Endocrinology and Metabolism 199984 1762. (https://doi.org/10.1210/ jcem.84.5.5677-7)

88 Wang C \& Crapo LM. The epidemiology of thyroid disease and implications for screening. Endocrinology and Metabolism Clinics of North America 199726 189-218.

89 Rubio-Tapia A, Ludvigsson JF, Brantner TL, Murray JA \& Everhart JE. The prevalence of celiac disease in the United States. American Journal of Gastroenterology 2012107 1538-1544. (https://doi.org/10.1038/ ajg.2012.219)

90 Webb C, Norstrom F, Myleus A, Ivarsson A, Halvarsson B, Hogberg L, Lagerqvist C, Rosen A, Sandstrom O, Stenhammar L et al. Celiac disease can be predicted by high levels of anti-tissue transglutaminase antibodies in population-based screening. Journal of Pediatric Gastroenterology and Nutrition 201560 787-791. (https://doi. org/10.1097/mpg.0000000000000688)

91 Catassi C, Ratsch IM, Fabiani E, Rossini M, Bordicchia F, Candela F, Coppa GV \& Giorgi PL. Coeliac disease in the year 2000: exploring the iceberg. Lancet 1994343 200-203.

92 Fasano A, Berti I, Gerarduzzi T, Not T, Colletti RB, Drago S, Elitsur Y, Green PH, Guandalini S, Hill ID et al. Prevalence of celiac disease in at-risk and not-at-risk groups in the United States: a large multicenter study. Archives of Internal Medicine 2003163 286-292.

93 Toh BH, van Driel IR \& Gleeson PA. Pernicious anemia. New England Journal of Medicine 1997337 1441-1448. (https://doi.org/10.1056/ nejm199711133372007)

Received 19 June 2018

Revised version received 16 October 2018

Accepted 30 November 2018 